\title{
Formation of Yttrium Oxide Composite Films by Electrodeposition in Organic Solutions
}

\author{
Yoshiharu MATSUDA*, Manabu YAMATANI*, Nobuko YOSHIMOTO*, \\ Masayuki MORITA*, Masashi ISHIKAWA* and Masaki HAGA** \\ 有機溶媒からの電析によるイットリウム複合酸化物の作製
}

松田好晴*, 山谷 学*, 吉本信子*, 森田昌行*, 石川正司*, 芳賀正記**

Key Words : Yttrium Oxıde, Electrodeposition, DMF-based Solutions, Fluorescent Materials, Composite Films

\section{Introduction}

Many of rare earth compounds are known as advanced materials for optical, magnetic, electric and electronic uses. For example, yttrium oxide films, excellent substrates for fluorescent materials, are now produced by dry processes, vapor deposition, sputtering, etc. 'If we can apply electrochemical methods to the preparation of such thin films, it would be very advantageous from the view point of the cost and productivity. However, it is difficult to obtain rare earth metals by electrodeposition due to their negative reduction potentials. In order to prevent the cathodic hydrogen evolution, non-aqueous solvents have been used for the electrolyte solutions. Several workers have reported the electrodeposition of rare earth compounds using organic solutions ${ }^{1) \sim 4)}$. We have also investigated the cathodic electrodeposition of rare earth films from organic baths ${ }^{5), 6)}$. We obtained the films of yttrium oxide and yttrium-europium oxıde from organic electrolytes containing small amounts of water ${ }^{7}$.

In the present work, the formation of lanthanide-containing yttrium oxide has been investigated in dimethylformamide (DMF)-based solutions, and then the composition and the fluorescent properties of the deposited films were briefly examined.

\section{Experimental}

The electrolytic cell was a glass beaker with a copper plate cathode, two parallel glassy carbon

* Fac. of Eng., Yamaguchı Unıv. (2557, Tokiwadai Ubeshi, Yamaguch 755 , Japan) 山口大学 工学部

** Ishihara Chemical Co., Ltd. (5-26, Nishiyanagihara-cho, Hyogo-ku, Kobe-shı, Hyogo 652, Japan)

石原薬品侏) plate anodes and a saturated calomel electrode (SCE) as the reference electrode. The solvent DMF was distilled at reduced pressure under an Ar atmosphere before use. Anhydrous $\mathrm{YCl}_{3}$ (Soekawa Chem. Co. Ltd.), $\mathrm{TbCl}_{3} \cdot 6 \mathrm{H}_{2} \mathrm{O}$ (High Purity Chem. Co. Ltd.) and $\mathrm{AlCl}_{3}$ (Soekawa Chem. Co. Ltd.) were used as the electrolytic salts. The water content in the electrolytic cell was determined by Karl Fischer titration. The electrodeposition was performed using a constant-d. c. power supply (Nichıa Keikı HP-5-1B). The morphology of the deposited films was observed by scanning electron microscopy (SEM). Electron probe microanalysis (EPMA) was also used to analyse the plated films. Photoluminescence spectroscopy was performed under the atmospheric conditions.

\section{Results and Discussion}

To investigate the electrodeposition process of the rare earth composite films, we have first carried out cyclic voltammetry (CV) in DMF containing rare earth ions. Fundamental behavior of $\mathrm{Y}^{3+}$ in DMF was described in a previous paper ${ }^{7)}$. In the solution containing $\mathrm{Tb}^{3+}$, the first potential sweep clearly indicated a cathodic current peak at about $-2.5 \mathrm{~V}$ (vs. SCE), suggesting the formation of terbium as shown eq. (1).

$\mathrm{Tb}^{3+}+3 \mathrm{e}^{-} \rightarrow \mathrm{Tb} \cdots \cdots \cdots \cdots \cdots \cdots \cdots \cdots \cdots \cdots \cdots \cdots \cdots(1)$

Also, the current shoulder observed at about $-1.0 \mathrm{~V}$ (vs. SCE) shows the possibility of $\mathrm{Tb}_{2} \mathrm{O}_{3}$ formation (eq. (2)).

$$
2 \mathrm{~Tb}^{3+}+3 \mathrm{H}_{2} \mathrm{O}+6 \mathrm{e}^{-} \rightarrow \mathrm{Tb}_{2} \mathrm{O}_{3}+3 \mathrm{H}_{2} \cdots \cdots(2)
$$

These results revealed that the electro-co-deposition of yttrium and terbium would be performed from DMF solutions containing $\mathrm{Y}^{3+}$ and $\mathrm{Tb}^{3+}$ with small amounts of water. In fact, we obtained thin films with white color and uniform surfaces by the constant-current electrodeposition From the SEM observation, however, the depo- 

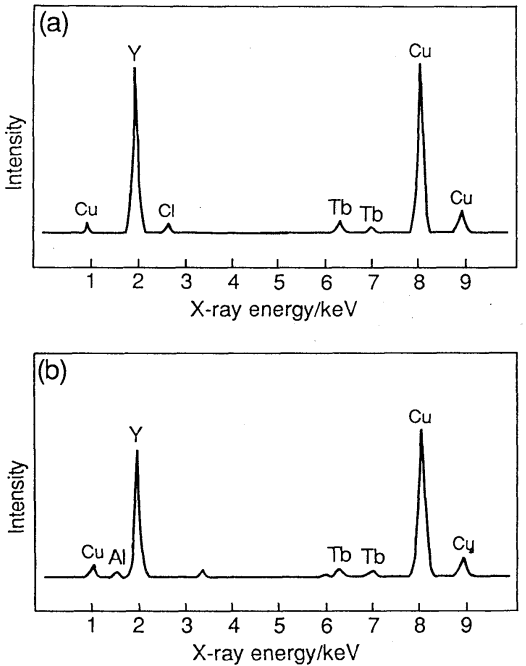

Fig. 1 EPMA spectra for films on $\mathrm{Cu}$ substrate by direct current deposition.

Bath : (a) $0.1 \mathrm{~mol} \mathrm{dm}{ }^{-3} \mathrm{YCl}_{3}+0.01 \mathrm{~mol} \mathrm{dm}^{-3} \mathrm{TbCl}_{3}$. $6 \mathrm{H}_{2} \mathrm{O} / \mathrm{DMF}$,

(b) $0.1 \mathrm{~mol} \mathrm{dm}{ }^{-3} \mathrm{YCl}_{3}+0.01 \mathrm{~mol} \mathrm{dm}{ }^{-3} \mathrm{TbCl}_{3}$. $6 \mathrm{H}_{2} \mathrm{O}+0.05 \mathrm{~mol} \mathrm{dm}^{-3} \mathrm{AlCl}_{3} / \mathrm{DMF}$

Current density : $1 \mathrm{~A} \mathrm{~m}^{-2}$

Electricity passed : $5.0 \times 10^{4} \mathrm{C} \mathrm{m}^{-2}$

sited film had many micro-cracks. Figure 1 (a) shows the EPMA spectrum of the film deposited from DMF containing $\mathrm{Y}^{3+}$ and $\mathrm{Tb}^{3+}$. In addition to the spectra for the copper substrate, $\mathrm{X}$-ray peaks based on yttrium and terbium were observed. We also examined the electro-codeposition of $\mathrm{Y}-\mathrm{Tb}-\mathrm{Al}$ oxide system, relating to $\mathrm{Y}_{3} \mathrm{Al}_{5} \mathrm{O}_{12}: \mathrm{Tb}$ with green color luminescence, from DMF containing $\mathrm{YCl}_{3}, \mathrm{TbCl}_{3}$ and $\mathrm{AlCl}_{3}$.

Figure 1 (b) shows the EPMA spectrum of the resulting film. The peaks of yttrium $\left(\mathrm{L}_{a}\right)$, terbium $\left(\mathrm{L}_{\alpha}, \mathrm{L}_{\beta}\right)$ and aluminum $\left(\mathrm{K}_{\alpha}\right)$ shows that the film obtained by the electrodeposition consisted of yttrium, terbium and aluminum. The fluorescence spectra of the films are shown in Fig. 2. Typical luminescence for $\mathrm{Y}_{3} \mathrm{Al}_{5} \mathrm{O}_{12}$ : $\mathrm{Tb}$ was observed at $490.5 \mathrm{~nm}$. This is attributed to the ${ }^{5} \mathrm{D}_{4} \rightarrow{ }^{7} \mathrm{~F}_{6}$ transition. Also the luminescence at the range from 542.5 to 621.0 seems to correspond to the transition of ${ }^{5} \mathrm{D}_{4} \rightarrow{ }^{7} \mathrm{~F}_{5}$ and ${ }^{5} \mathrm{D}_{4} \rightarrow{ }^{7} \mathrm{~F}_{3}{ }^{8)}$. These suggest that the films obtained by the electrodeposition are candidates for luminescent material.

\section{Conclusion}

We obtained films consisting of yttrium, alumi-

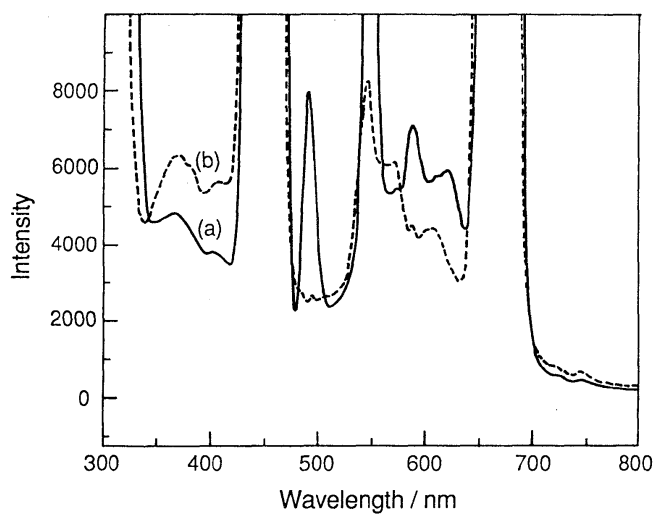

Fig. 2 Fluorescence spectra (a) for a deposited film on $\mathrm{Cu}$ substrate by direct current deposition, and (b) for $\mathrm{Cu}$ substrate.

Bath : $0.1 \mathrm{~mol} \mathrm{dm}{ }^{-3} \mathrm{YCl}_{3}+0.01 \mathrm{~mol} \mathrm{dm} \mathrm{dm}^{-3} \mathrm{TbCl}_{3} \cdot$ $6 \mathrm{H}_{2} \mathrm{O}+0.05 \mathrm{~mol} \mathrm{dm}^{-3} \mathrm{AlCl}_{3} / \mathrm{DMF}$

Current density : $1 \mathrm{~A} \mathrm{~m}^{-2}$

Electricity passed : $5.0 \times 10^{4} \mathrm{C} \mathrm{m}^{-2}$

num, terbium and/or their oxides by electro-codeposition in DMF containing $\mathrm{YCl}_{3}, \mathrm{TbCl}_{3}, \mathrm{AlCl}_{3}$ and small amounts of water. The films have potential of the terbium luminescent materials.

We are grateful to The Ministry of Education, Science and Culture for a financial support on Priority Areas "New Development of Rare Earth Complexes" (Nos. 06241256 and 07230266).

(Received July 8, 1995 ; Accepted August 7, 1995)

\section{References}

1) T. Moeller and P. A. Zimmerman ; Science, 120, 539 (1954)

2 ) N. Usuzaka, H. Yamaguchi and T. Watanabe ; Mater Sci. Eng., 99, 105 (1988)

3) Y. Sato, H. Ishida, K. Kobayakawa and Y. Abe ; Chem. Lett., 1471 (1990)

4 ) Y. Sato, T. Takazawa, M. Takahashi, H. Ishida and K. Kobayakawa ; Plating and Surface Finishing, 90, 72 (1993)

5 ) Y. Matsuda, T. Fujii, N. Yoshimoto, M. Morita and M. Haga ; J. Alloys and Compounds, 193, 23 (1993)

6 ) Y. Matsuda, K. Imahashi, N. Yoshimoto, M. Morita and M. Haga ; J. Alloys and Compounds, 193, 277 (1993)

7 ) Y. Matsuda, K. Imahashi, N. Yoshimoto, M. Morita and M. Haga ; J. Surf. Finish. Soc. Jpn., 44, 672 (1993)

8 ) J. Shiokawa (ed.) ; " Latest Applied Technology of Rare Earth ”, p. 120 (CMC Co. Ltd., 1985) 